\title{
Student engagement in Higher Education, age and parental education level
}

\author{
Envolvimento dos estudantes no Ensino Superior, \\ idade e habilitações acadêmicas dos pais
}

\author{
Filomena COVAS ${ }^{1}$ iD 0000-0002-1570-4495 \\ Feliciano Henriques VEIGA² ID 0000-0002-2977-6238
}

\begin{abstract}
Within the scope of socio-cognitive theories, student engagement in school has been studied as a multidimensional construct. A four-dimensional perspective was adopted, with the dimensions: affective, cognitive, behavioural and agentic. The objective, to analyse how the variables age and parental education relate to student engagement in school. The sample consisted of 715 Portuguese public Higher Education students from the Lisbon area. The data was collected through an online survey, which included the Student Engagement in School: a Four-Dimensional Scale - Higher Education Version. Data analysis not only revealed that students of age 26 or older scored considerably higher results in engagement than younger colleagues, but also highlighted significant differences of engagement in the affective, behavioural and agentic dimensions, depending on parental education. The results, while partially corroborating the revised literature, suggest future in-depth studies.
\end{abstract}

Keywords: Higher education. Maternal education. Motivation. Paternal education.

\section{Resumo}

No âmbito das teorias sociocognitivas, o envolvimento do aluno na escola tem sido estudado como um constructo multidimensional. Para este estudo, optou-se por uma perspetiva quadridimensional a partir das dimensões afetiva, cognitiva, comportamental e agenciativa. Pretendeu-se analisar como as variáveis idade e escolaridade dos pais aparecem associadas ao envolvimento dos estudantes na escola. A amostra foi constituída em 715 estudantes portugueses do Ensino

$\because>0$

1 Instituto Politécnico de Lisboa, Escola Superior de Educação de Lisboa. Lisboa, Portugal.

${ }^{2}$ Universidade de Lisboa, Instituto de Educação. R. Alameda da Universidade, 1649-013, Lisboa, Portugal. Correspondence to: F.H. VEIGA. E-mail: <fhveiga@ie.ulisboa.pt>.

Article based on the thesis of F. COVAS, entitled "Envolvimento na escola e saúde mental dos estudantes de ensino superior". Universidade de Lisboa, 2020.

$\boldsymbol{v} \boldsymbol{v}$

How to cite this article

Covas, F., \& Veiga, F. H. (2021). Student engagement in Higher Education, age and parental education level. Estudos de Psicologia (Campinas), 38, e200020. https://doi.org/10.1590/1982-0275202138e200020 
Superior Politécnico público da região de Lisboa. Os dados foram recolhidos através de um inquérito online que incluiu a escala, Envolvimento dos Alunos na Escola: uma Escala Quadri-Dimensional - Versão para Ensino Superior. A análise dos dados destacou que estudantes com 26 ou mais anos mostraram resultados no envolvimento significativamente superiores aos colegas mais jovens e salientou diferenças significativas no envolvimento deles nas dimensões afetiva, comportamental e agenciativa em função do nível de escolaridade dos pais. Os resultados corroboraram parcialmente a literatura revista e sugerem futuros estudos de aprofundamento.

Palavras-chave: Educação superior. Escolaridade materna. Motivação. Escolaridade paterna.

In the last decades, the study of Student Engagement at School (SES) has been developed in the context of Higher Education, due to the growing concern with school dropout, which has affected a significant part of students who do not complete their academic courses, and also to the fact that studies conducted in a pre-university education context mention that engagement may be an important factor in combatting school dropout (Appleton, Reschly, \& Christenson, 2014; Furlong \& Christenson, 2008; Veiga, 2013). Studies have shown that student engagement is associated to personal and contextual factors (Abreu \& Veiga, 2014; Raftery, Grolnick, \& Flamm, 2012) and that this sensitivity to personal variables (e.g. gender, emotional state) and contextual ones (e.g. school and family practices) is what constitutes its fundamental characteristic of malleability (Fredricks, Blumenfeld, \& Paris, 2004). In this way, the deepening of the knowledge of the quality of relationships between the personal factors, contextual ones and student engagement may help contribute to the creation of educational strategies which promote engagement at school for all students (Dias, Oliveira, Moreira, \& Rocha, 2015; Reeve \& Shin, 2020). The presented research was conducted with Portuguese Higher Education students and sought to analyse how to differentiate the results in SES depending on the variables of age and parental education. A brief theoretical framework of the concept is presented, some studies about the relationship between SES and the variables under study, the methodology, results and a discussion along with respective conclusions and final considerations.

\section{Conceptual Framework}

Student Engagement at School is considered a complex and multifaceted concept that has been the focus of considerable attention, in specialised literature, in the last years. The first contextualisation of the concept were accomplished in the scope of the student psychosocial disengagement theories, establishing a strong connection between SES and a series of educational factors, such as academic performance, participation, satisfaction, persistence, academic realisation and social commitment (Finn, 1989). In a recent literature review about the conceptual framework of Higher Education engagement, Kahu (2013) identifies four approaches: the behavioural which centres itself on the study of experiences and behaviours of students; the psychological which studies engagement as an individual internal process; the sociocultural which highlights the influence of contextual factors; and the holistic perspective which seeks to integrate the three aforementioned approaches (Kahu, 2013). In this holistic model, the central process of SES is associated with the affective, cognitive and behavioural dimensions. At a proximal level: on one hand, the psychosocial influences connected to the institution (type of education, teacher support), to the academic relationships and variables (motivation, self-efficacy and skills); and on the other hand, the consequences, such as learning, academic success and well-being. At a more distant level, as antecedent aspects, the structures associated with the factors related to the institution and to the student's environment (e.g., institutional policies and practices, family support, cultural level) and, as consequent aspects, school retention, success in work, lifelong learning and civic participation. The most highlighted characteristic of this conceptual model is its network structure, in that its relationships with the influences and the consequences, of the proximal

2 and distant levels, are bi-directional and all of this complex process of interrelations is contextualised in the 
even more comprehensive scope of sociocultural and socio-political influences (Kahu \& Nelson, 2018). One may say that the complexity of the perspectives that influence the study of SES relates to the need for a global reform of the education system (Fardella-Cisternas, Campos, \& Vargas, 2017), with school dropout prevention and with SES concept clarification with regards to motivational literature of psychological sciences (Reschly \& Christenson, 2012). SES has been considered a multidimensional construct that covers aspects of students related to emotions, behaviours and to the processes of learning and knowledge building. It has been studied under various perspectives according to its attributed dimensions, which can vary from one to four (Fredricks \& McColskey, 2012; Reeve \& Tseng, 2011). The studies on SES considered to be pioneers presented a bi-dimensional model referring to the behavioural (e.g. effort, participation) and affective dimensions (e.g. feeling of belonging, identifying with school, interest) (Finn, 1989). Other studies followed in which a tri-dimensional model was chosen, adding the cognitive dimension, described through the processes of self-regulation or investment in learning (Fredricks et al., 2004). Specifically, in the context of Portuguese Higher Education, there are studies on validation of the Inventário de Envolvimento Académico dos Estudantes do Ensino Universitário (University Student Engagement Inventory), an instrument constituted by 15 items equitably distributed across three dimensions, behavioural, cognitive and emotional adapted to the Portuguese university context taking from the studies of Sinval, Casanova, Marôco, and Almeida (2018), revealing levels of internal consistency (Cronbach's alpha) between 0.69 to 0.87 . In the present research, the choice to use the Student Engagement in School, a Four-Dimensional Scale (SES-4DS), by Veiga (2013, 2016), was due to this instrument's ability to evaluate a construct comprising aspects connected to four dimensions: cognitive, related to the investment the student makes in constructing metacognitive and selfregulating strategies of his learning; behavioural, in reference to responsible participation and in accordance to the current directives of school context; affective, with respect to the emotional process of linkage and integration in school context; and agentic, connected to a proactive process by which the student is able to appropriate learning in a personal and significant sense (Matos, Reeve, Herrera, \& Claux, 2018; Reeve \& Tseng, 2011; Veiga, 2013, 2016).

It should be noted that consensus exists in considering that Higher Education institutions hold as leading purposes the construction and disclosure of knowledge, the development of the fondness for the process of learning and preparing students for social and professional life, in that they are capable of assuming a constructive and participative citizenship (Kahu \& Nelson, 2018). Hence, for the pursuit of such goals, it is considered fundamental that a high SES exists, particularly in the agentic dimension, in that this component implies the active construction of a reflexive process, of learning appropriation (Reeve \& Tseng, 2011; Veiga, 2013). The current investigation is justified by the gap of knowledge at the level of the Portuguese Higher Education context, specially, with respect to the differentiation of SES results in function of the variables of age and parental education, whether in relation to global engagement, whether to any one of the four dimensions considered herein.

\section{Engagement and age}

The growing demand for professional gradation, in the working environment, has originated an increase in population on Higher Education students with different characteristics from the traditional group of students (Almeida \& Cruz, 2010) which are located between the ages of 18 and 25. The students, unlike the usual ones, have been designated non-traditional students (Almeida \& Casanova, 2019; Novotný, Brücknerová, Juhaňák, \& Rozvadská, 2019). This designation arose to describe groups that were underrepresented in Higher Education, students of age 26 or higher, more mature, with family responsibilities, who did not enter Higher Education right after High School, and, at times, also belonging to ethnic minorities (Novotný et al., 2019; Woods \& Frogge, 2017). The results of Freund, Hennecke, and Riediger (2010), on the learning differences as a function of age, show that the older subjects tend to have a greater orientation 
for the process, while the subjects under 25 tend to focus more on the results. The investigators underlined that the guidance in the process was predictive of emotional satisfaction and higher motivational levels. Complementary, another study (Lam, Yim, Law, \& Cheung, 2004) highlights results indicating that students, when more focused on the learning process and less on results, tend to reveal higher levels of cognitive engagement, intrinsic motivation, learning effort and persistence in face of failure. In the same way, results of a study with 128 university students (Timms, Fishman, Godineau, Granger, \& Sibanda, 2018) show that students of age higher than 25 reported higher levels of engagement in learning. The study of Burton, Taylor, Dowling, and Lawrence (2009) too, corroborates previous results, showing students over 25 use a deeper study approach, with meaning discovery, while the younger ones adopt more superficial strategies directed towards immediate results.

\section{Engagement and parental educational}

In the context of Higher Education, a few studies can be found to analyse the relationship between parental education and Higher Education course choices or between the parents' sociocultural classes and academic performance (Holmes, Gore, Smith, \& Lloyd, 2018; McMaster, 2019; Toledo \& Martínez, 2019). Studies on the connection between parental education and SES were not found. This scarcity may be linked to the fact that the ideas concerning parents have been neglected, in part due to influence of theories on the development of the young adult which, by attributing a crucial role to the autonomy and independence of young students, influenced the construction of stereotypes on the participation of parents in Higher Education, considering it to be intrusive (Kiyama \& Harper, 2018). However, in the context of pre-university education, attention has been drawn to relationships of several family-related factors with academic performance and with SES, such as family structure, family support and parental practices (Raftery et al., 2012). The obtained results are in line with indicating a positive correlation between these factors and SES, in its varied dimensions, with emphasis on the idea that the fundamental factor is the student's perception of the parents' support (Abreu \& Veiga, 2014). This family support, as perceived by the student, seems to have a very positive influence on adaptation, academic performance and effort placed into accomplishing school assignments, and attitude towards school (Abreu \& Veiga, 2014; Veiga \& Antunes, 2005; Veiga et al., 2016). Other studies performed in High School context also show consistent results with the previously mentions researches, stressing that the parental education variable is positively associated with SES (Erol \& Turhan, 2019).

\section{Method}

\section{Participants}

In the present investigation a quantitative methodology was used, with a sample of 715 undergraduate students of four public Higher Education institutions in the Lisbon region. The sample included 364 (50.9\%) female students and 351 (49.1\%) male. As for age, the answers varied between 18 and 65 years old and 41 students did not answer this question. The mean age was found to be 26.14 (SD =9.02) and over half of the students (64.1\%) were under 26. The students attended four fields of study: Education and Social Communication (23.6\%); Accounting and Management (35.8\%), and Engineering (40.6\%). As for course year distribution, $39.0 \%$ of students were first year, $24.2 \%$ second year and $36.8 \%$ third and fourth years. Relatively to the paternal education level: $24.2 \%$ had a low level of education (lower or equal to Primary School); 56.8\% had an intermediate level (Middle or High School); and 29.0\% had a high level (University). As for the maternal education level: $24.7 \%$ had a low level of education; $45.9 \%$ had an intermediate level; and $29.5 \%$ had a high level. 


\section{Instruments}

The enquiry included a socio demographic and Student Engagement in School: a Four-Dimensional Scale - Higher Education Version (SES-4DS/HEV), by Veiga $(2013,2016)$, an instrument initially intended for the Primary and Middle School population, with adaptations also made in different studies in Brazil (Campos, 2019; Silveira \& Justi, 2018). The SES-4DS / HEV is comprised of 20 items, of Likert-like response, which may vary between 1 (total disagreement) and 6 (total agreement), distributed equitably across the four dimensions, each of the engagement dimensions is assessed through a set of five items. By way of example, a few items in each of the four dimensions stand out: in the cognitive (e.g., "When I am reading I try to understand what the author wants to convey"); in the affective (e.g., "My school is a place where I make friends with ease"); in the behavioural (e.g., "I'm distracted in class"); and in the agentic (e.g., "During class, I intervene to express my opinions"). In the adaptation towards a Higher Education context (Covas \& Veiga, 2017), the great majority of the items kept the formulation of the original version, with the exception of item number 13 which went from "I am rude to the teacher" to "I disturb class with conversations that have nothing to do with class matters," and item number 14 went from "I am rude to the teacher" to "I behave in a way which shows lack of respect for my teachers." Said change contemplated a preliminary study in which the authors (Covas \& Veiga, 2017) proceeded to analyse the frequency of answers per item, with the intent of assessing the pertinence of the content of the items and proceeded to their alteration in a search for greater proximity to the experiences of students in Higher Education. In this sense, again in a study of SES-4DS / HEV adaptation (Fernandes, Caldeira, Silva, \& Veiga, 2016) conducted with a sample of Portuguese university undergraduate students, the same items 13 e 14 were eliminated due to jeopardizing the internal consistency of the instrument. In the Covas and Veiga (2017) study, the analysis of the relational structure for the SES-4DS/HEV items was carried out through exploratory factorial analysis, extracting factors by method of main components, followed by varimax rotation, and converted to a four main components solution which explained $61.14 \%$ of total variance. In the study of original scale, the total variance explained by the four factors was $57.90 \%$ (Veiga, 2013). Also, in the study of Covas and Veiga (2017), the numbers of internal consistency (Cronbach's alpha) of SES-4DS/HEV varied between a minimum of 0.76 , in the behavioural dimension, and a maximum of 0.91 in the affective dimension, very close to those found in the original studies of Veiga $(2013,2016)$ in a pre-university education context. In conclusion, the instrument proved to have good internal consistency and relational structure, allowing its continued use in research conducted in the context of Higher Education.

\section{Procedures}

Data was collected through an enquiry by online survey, which was sent directly to the students' institutional emails (approximately 7,000), previously made available by the respective governing bodies of the involved institutions. 1,085 surveys were received (about 15\% of total sent), of which 370 were excluded for incompletion or inconsistency. An online version of the survey was created using Limesurvey software and the data collected exported directly to the statistical analysis Software IBM ${ }^{\circledR}$ SPSS ${ }^{\circledR}$ (version 23). The data was subjected to a descriptive statistical analysis, emphasising on mean values, standard deviation, and on answer frequency per item. The study of the result differentiation in SES as a function of age was performed through test $t$ and the study in function of parental education was achieved through the ANOVA oneway. The level of significance taken as reference was $p \leq 0.05$. Over the course of the research, the author sought to respect ethical principles with regards to the necessary precautions for the protection of the participants, their written consent, confidentiality, privacy as well as for the protection of data collected. In the beginning of the survey an informative text was presented which explained the goals of the investigation, emphasising the voluntary nature of participation, the freedom whether to answer or not, and assured the confidentiality, privacy and anonymity of the answers. The participants were at no time required to identify themselves and, 
although the survey was conducted online, the answers were received with a unique code generated by the software program. A formal judgement of the matter was requested of the Comissão de Ética do Instituto de Educação da Universidade de Lisboa (Ethics Committee of the Institute of Education of the University of Lisbon), through file reference number 1029.

\section{Results}

\section{Results as a function of age}

Results as a function of age were grouped into two categories: students aged under 26 and students of age 26 or higher. Table 1 shows the results in SES as a function of age. The analysis of the results showed statistically significant differences in the engagement - total scale $(p<0.001)$; agentic dimension $(p<0.001)$; behavioural dimension $(p<0.001)$; and cognitive dimension $(p<0.001)$, with higher scores in the 26 or higher group. In the affective dimension, no statistically significant differences were observed.

Table 1

Mean and standard deviation of results in Student Engagement in School dimensions as a function of age

\begin{tabular}{|c|c|c|c|c|c|c|}
\hline \multirow{3}{*}{ Dimensions } & \multicolumn{4}{|c|}{ Age } & \multirow{3}{*}{$t$} & \multirow{3}{*}{ Sig } \\
\hline & \multicolumn{2}{|c|}{$\begin{array}{c}<26 \text { years old } \\
(N=432)\end{array}$} & \multicolumn{2}{|c|}{$\begin{array}{c}\geq 26 \text { years old } \\
\quad(N=242)\end{array}$} & & \\
\hline & $M$ & $S D$ & $M$ & $S D$ & & \\
\hline Affective & 23.93 & 5.01 & 23.52 & 4.39 & 1.05 & 0.293 \\
\hline Agentic & 17.32 & 5.59 & 19.71 & 4.90 & -5.55 & $0.001^{* * *}$ \\
\hline Behavioural & 24.99 & 4.27 & 27.24 & 3.01 & -7.24 & $0.001^{* * *}$ \\
\hline Cognitive & 20.36 & 3.69 & 21.75 & 3.61 & -4.73 & $0.001^{* * *}$ \\
\hline Student Engagement in School - total scale & 86.60 & 12.12 & 92.21 & 10.88 & -5.99 & $0.001^{* * *}$ \\
\hline
\end{tabular}

Note: ${ }^{* * *} p<0.001 . t$ : T-test; Sig: Significance; M: Mean; SD: Standard Deviation.

\section{Results as a function of parental education}

Parental education was classified in the following groups: low level, including answers such as "no schooling," "Primary School;" intermediate level, including answers such as "Middle School" and "High School;" and high level, including answers such as "associate," "bachelor," "master" and "doctor." This division sought the balance of the dimension of the groups, avoiding eventual statistical disturbances. The paternal and maternal education levels were considered separately, given lack of previous studies. The results in SES as a function of paternal education are presented on Table 2.

The presented results, as a function paternal education, allow the observation of statistically significant differences in the following dimensions: total engagement $(F(2,649)=4.515, p=0.011)$; agentic dimension $(F(2,649)=3.118, p=0.045)$; behavioural dimension $(F(2,649)=9.643 p=0.001)$; and cognitive dimension $(F(2,649)=3.642, p=0.027)$. The Post-Hoc test by Scheffe revealed that the group of students with fathers of the low level of education showed a significantly higher total engagement scale, although already at the threshold of statistical significance $(p<0.05)$, than that of the group of students with fathers of the intermediate level, but not statistically superior to that of the group of students with fathers of the high level. In the agentic dimension, the groups of students with fathers of the low and high levels showed significantly superior results $(p<0.05)$ over the group with fathers of the intermediate level. In the behavioural dimension it was the group with fathers of the low level that scored a higher engagement ( $p<0.001$ and $p<0.01$, respectively) than that of the groups with fathers of the intermediate and high

6 levels. In the cognitive dimension, the group with fathers of the low level showed significantly superior 
results in engagement $(p<0.05)$ over the group with fathers of the intermediate level, but not significantly different than those of the group with fathers of the high level. In the affective dimension, no statistically significant differences were observed. Shown below, on Table 3, the results in SES as a function of maternal education.

Table 2

Results in Student Engagement in School dimensions as a function of paternal education - ANOVA oneway (F)

\begin{tabular}{|c|c|c|c|c|}
\hline \multirow{2}{*}{ Dimensions/Level } & \multicolumn{4}{|c|}{ Paternal education level } \\
\hline & $N$ & M & $S D$ & $F(2,649)$ \\
\hline \multicolumn{5}{|l|}{ Affective } \\
\hline Low & 158 & 23.08 & 4.98 & \multirow{3}{*}{1.78} \\
\hline Intermediate & 305 & 23.60 & 4.87 & \\
\hline High & 189 & 24.07 & 4.83 & \\
\hline \multicolumn{5}{|l|}{ Agentic } \\
\hline Low & 158 & 18.54 & 5.78 & \multirow{3}{*}{$3.12^{*}$} \\
\hline Intermediate & 305 & 17.47 & 5.41 & \\
\hline High & 189 & 18.54 & 5.26 & \\
\hline \multicolumn{5}{|l|}{ Behavioural } \\
\hline Low & 158 & 26.84 & 3.70 & \multirow{3}{*}{$9.64^{* * *}$} \\
\hline Intermediate & 305 & 25.12 & 4.18 & \\
\hline High & 189 & 25.61 & 3.94 & \\
\hline \multicolumn{5}{|l|}{ Cognitive } \\
\hline Low & 158 & 20.47 & 3.65 & \multirow{3}{*}{$3.64^{*}$} \\
\hline Intermediate & 305 & 20.79 & 3.69 & \\
\hline High & 189 & 20.80 & 3.67 & \\
\hline \multicolumn{5}{|c|}{ Student Engagement in School - total scale } \\
\hline Low & 158 & 89.90 & 12.29 & \multirow{3}{*}{$4.52^{* *}$} \\
\hline Intermediate & 305 & 86.67 & 12.24 & \\
\hline High & 189 & 89.01 & 11.21 & \\
\hline
\end{tabular}

Note: ${ }^{*} p<0.05 ;{ }^{* *} p<0.01 ;{ }^{* * *} p<0.001$. M: Mean; SD: Standard Deviation.

Table 3

Results in Student Engagement in School dimensions as a function of maternal education - ANOVA oneway (F)

\begin{tabular}{|c|c|c|c|c|}
\hline \multirow{2}{*}{ Dimensions/Level } & \multicolumn{4}{|c|}{ Maternal education level } \\
\hline & $N$ & M & $S D$ & $F(2,662)$ \\
\hline \multicolumn{5}{|l|}{ Affective } \\
\hline Low & 164 & 22.57 & 5.62 & \multirow{3}{*}{$5.18^{* *}$} \\
\hline Intermediate & 305 & 23.92 & 4.69 & \\
\hline High & 196 & 24.06 & 4.53 & \\
\hline \multicolumn{5}{|l|}{ Agentic } \\
\hline Low & 164 & 18.57 & 5.57 & \multirow{3}{*}{0.97} \\
\hline Intermediate & 305 & 17.89 & 5.30 & \\
\hline High & 196 & 17.90 & 5.60 & \\
\hline \multicolumn{5}{|l|}{ Behavioural } \\
\hline Low & 164 & 26.89 & 3.36 & \multirow{3}{*}{$10.01^{* * *}$} \\
\hline Intermediate & 305 & 25.19 & 4.33 & \\
\hline High & 196 & 25.46 & 3.99 & \\
\hline \multicolumn{5}{|l|}{ Cognitive } \\
\hline Low & 164 & 21.15 & 3.40 & \multirow{3}{*}{1.40} \\
\hline Intermediate & 305 & 20.57 & 3.83 & \\
\hline High & 196 & 20.69 & 3.57 & \\
\hline \multicolumn{5}{|c|}{ Student Engagement in School - total scale } \\
\hline Low & 164 & 89.18 & 12.08 & \multirow{3}{*}{0.95} \\
\hline Intermediate & 305 & 87.57 & 12.43 & \\
\hline High & 196 & 88.12 & 11.40 & \\
\hline
\end{tabular}

Note: ${ }^{* *} p<0.01 ;{ }^{* * *} p<0.001$. M: Mean; SD: Standard Deviation. 
In the results presented as a function of maternal education, statistically significant differences were observed in the affective dimension $(F(2,662)=5.175, p=0.006)$ and in the behavioural dimension $(F(2,662)=10.013, p=0.001)$. The Post-Hoc test by Scheffe revealed that, in the affective dimension, the group of students with mothers of the high level of education showed a significantly superior engagement $(p<0.05)$ to that of the other two groups with mothers of the low and intermediate levels. In the behavioural dimension, the group with mothers of the low level showed statistically superior results $(p<0.001$ and $p<0.01)$, in relation to the other two groups with mothers of the intermediate and high levels. In the remaining dimensions no statistically significant differences were observed.

\section{Discussion}

The results as a function of age are in accordance with the revised literature (Burton et al., 2009; Freund et al., 2010; Lam et al., 2004; Timms et al., 2018). One should note that students of age over 25 are, in general rule, more mature, have been through life experiences which have required greater family and professional commitment, may have already enrolled other Higher Education courses and may thereby be more aware of their choices and sure of their life goals (Woods \& Frogge, 2017). These older students have already built a sense of identity with greater awareness of the person they are and their subjective vision of the world and, on the social domain, they have already developed more mature relationship patterns with their peers, teachers and family, and in the vocational scope have already discovered their professional orientation, having some of them already transited to the professional world (Almeida \& Cruz, 2010). Such elements would justify their significant superiority in SES. Other authors refer to the existence of significant differences in learning as a function of age (Freund et al., 2010), noting that older persons tend to focus on the process and not so much on immediate results, as do younger ones. Older students in general use deeper study approaches with meaning discovery (inherent trait of the agentic dimension of SES), while younger ones adopt superficial strategies usually steered towards immediate results (Burton et al., 2009). Other studies showed that older students, usually, reach higher levels on SES, on the cognitive dimension, in intrinsic motivations, in learning effort and persistency in face of failure (Lam et al., 2004; Timms et al., 2018).

Concerning parental education, the superiority of the results of students with fathers and mothers of the high level of education, in the agentic dimension and affective, respectively, corroborated the results found in studies conducted in a pre-Higher Education context (Abreu \& Veiga, 2014; Erol \& Turhan, 2019; Raftery et al., 2012; Veiga \& Antunes, 2005; Veiga et al., 2016). Most likely the parents who attended Higher Education may have experienced a more significant way of learning, thus passing on, in their child's education, a more critical and reflexive attitude towards the construction of knowledge, which may explain the superior results in the agentic dimension. As for the superiority of results referring students with mothers of the high level, in the affective dimension, results may suggest that these mothers who attended Higher Education, probably pass on to their child an affective ambient, with a feeling of belonging and linkage to the school, which nourishes the desire to belong and to feel more integrated with the academic group of reference. These possible explanations related to the high scores of students with a father or mother of the high level, in the agentic and affective dimensions, respectively, may be connected to sociocultural aspects related to the paternal prevalence in social and ludic development, and to the maternal prevalence in emotional regulation of the child (Aboim, 2010; Monteiro, Fernandes, Torres, \& Santos, 2017). In contrast, the superiority of the results of students with fathers of the low level, in relation to those with fathers of the intermediate one in total engagement and in all dimensions, except for affective, as well as significantly superior results in the behavioural dimension in comparison with students with fathers of the high level, seems to go against results from studies conducted in pre-Higher Education context. In a search for explanations for these results,

8 one considers the possibility that it might result from parents transmitting their own unmet aspirations of 
academic success. Or it could be linked to the desire to satisfy a need for social and economic recognition, since, usually, academic success is connected to the perception of a higher sociocultural and economic status. It is possible that this group of students with fathers of low level academic qualifications be influenced by pity, conveyed by their fathers, for not having been able to attend school and also, by the perception of the effort their fathers make for them to attend. Therefore, possibly developing a greater dedication to studying, greater proactivity in learning and respect for the values and rules of academic context. Elements such as these may produce a significant increase in their results in total engagement, in the cognitive, agentic and behavioural dimensions, in comparison to their colleagues with fathers of the intermediate level of academic qualifications. In what concerns SES results as a function of maternal education, results obtained in the behavioural dimension stand-out, with superiority of students with mothers of low level. Possibly these mothers convey a set of values of discipline and respect for school norms, connected to the idea that academic success is associated with good behaviour in school, which can positively influence the results of their child, in the behavioural dimension.

\section{Conclusion}

A few limitations of the presented research arise, related to the fact that it is a convenience-constituted sample and not random or probabilistic. Since the data collection was carried out through an online survey and participation was voluntary, the students who actually responded may have been those who showed greater engagement in school. Another limitation has to do with the use of self-reporting evaluation instruments, as all student answers may be subject to an effect of social desirability. Yet another limitation relates to the scarcity of national and international empirical studies, conducted in a Higher Education context, that make use of a four-dimensional evaluating scale of SES, which may compromise the comparison of results and weaken the possibility of generalizing them, in addition to the reservations that, in the field of research, any result generalization always entails. It is considered, nonetheless, that the analysis of the results put forth the importance of the variables studied in SES differentiation, partially corroborating the results of the revised literature. Results which, in the scope of the diverse Higher Education institutions, reiterate the significance of understanding which personal and social factors may be associated with student engagement, in order to define interventive strategies to lessen their effects and promote the engagement of all in a school for all. Thus the necessity remains for deepening studies of various factors which may be significantly associated with the construct of engagement, also recurring to qualitative methodologies of data collection from students, teachers and other possible education support technicians.

\section{Contributors}

F. COVAS was responsible for the discussion of results to the literature review, data analysis interpretation and manuscript preparation. F. H. VEIGA contributed to the general supervision and coordination, methodological design and interpretation.

\section{References}

Aboim, S. (2010). Gender cultures and the division of labour in contemporary Europe: a cross-national perspective. Sociological Review, 58(2), 171-196. https://doi.org/10.1111/j.1467-954X.2010.01899.x

Abreu, S., \& Veiga, F. H. (2014). Fatores familiares do envolvimento dos alunos na escola. In F. H. Veiga (Ed.), Envolvimento dos alunos na escola: perspetivas internacionais da psicologia e educação (pp. 176-195). Lisboa: FCT. Recuperado de http://cieae.ie.ul.pt/2013/wp-content/uploads/2014/11/E-Book_ICIEAE.pdf 
Almeida, L. S., \& Casanova, J. R. (2019). Desenvolvimento psicossocial e sucesso académico no ensino superior. In F. H. Veiga (Ed.), Psicologia da educação: temas de aprofundamento científico para a educação XXI (pp. 101-128). Lisboa: Climepsi.

Almeida, L. S., \& Cruz, J. F. A. (2010). Transição e adaptação académica: reflexões em torno dos alunos do 10 ano da Universidade do Minho. In J. L. Silva, F. Vieira, A. A. Carvalho, A. Flores, I. Viana, J. C. Morgado, ... N. Van Hanttum-Janssen (Eds.), Ensino superior em mudança: tensões e possibilidades. Actas do Congresso Ibérico (pp. 429-439). Braga: Universidade do Minho.

Appleton, J. J., Reschly, A. L., \& Christenson, S. L. (2014). Measuring and intervening with student engagement with school: theory and application, U.S. and international results, and systems level implementations. In F. H. Veiga (Ed.), Students' engagement in school: international perspectives of psychology and education (pp. 20-37). Retrieved from http://cieae.ie.ul.pt/2013/wp-content/uploads/2014/11/E-Book_ICIEAE.pdf

Burton, L., Taylor, J., Dowling, D., \& Lawrence, J. (2009). Learning approaches, personality and concepts of knowledge of first-year students: mature-age versus school leaver. Studies in Learning Evaluation Innovation and Development, $6(1), 65-81$.

Campos, L. (2019). Escala de engajamento dos alunos inferida pelo professor (Dissertação de mestrado não-publicada). Universidade de Juíz de Fora, Juíz de Fora, Brasil.

Covas, F., \& Veiga, F. (2017). Envolvimento dos estudantes no ensino superior: um estudo com a escala EAE-E4D. Revista de Estudios e Investigación en Psicología y Educación, 1, 121-126. https://doi.org/10.17979/reipe.2017.0.01.2416

Dias, A., Oliveira, J. T., Moreira, P. A. S., \& Rocha, L. (2015). Percepção dos alunos acerca das estratégias de promoção do sucesso educativo e envolvimento com a escola. Estudos de Psicologia (Campinas), 32(2), 187-200. https://doi. org/10.1590/0103-166X2015000200004

Erol, Y. C., \& Turhan, M. (2019). The relationship between parental involvement and engagement to school. International Online Journal of Educational Sciences, 10(5), 260-281. https://doi.org/10.15345/iojes.2018.05.017

Fardella-Cisternas, C., Campos, V. S., \& Vargas, F. J. (2017). University transformation and quantification devices. Estudos de Psicologia (Campinas), 34(3), 435-448. https://doi.org/10.1590/1982-02752017000300011

Fernandes, H. M. R., Caldeira, S. N., Silva, O. D. L., \& Veiga, F. H. (2016). Envolvimento dos alunos no ensino superior: um estudo com a Escala Quadridimensional de Envolvimento dos Alunos na Escola (EAE-E4D). In F. H Veiga (Ed.), Envolvimento dos alunos na escola: perspectivas da psicologia da educação motivação para o desempenho académico (pp. 47-76). Lisboa: FCT. Recuperado de http://hdl.handle.net/10400.3/4077

Finn, J. D. (1989). Withdrawing from school. Review of Educational Research, 59(2), 117-142. https://doi. org/10.3102/00346543059002117

Fredricks, J. A., Blumenfeld, P. C., \& Paris, A. H. (2004). School engagement: potential of the concept, state of the evidence. Review of Educational Research, 74(1), 59-109. https://doi.org/10.3102/00346543074001059

Fredricks, J. A., \& McColskey, W. (2012). The measurement of student engagement: a comparative analysis of various methods and student self-report instruments. In S. L. Christenson, A. L. Reschly, \& C. Wylie (Eds.), Handbook of Research on Student Engagement (pp. 763-782). New York: Springer. https://doi.org/10.1007/978-1-4614-2018-7

Freund, A. M., Hennecke, M., \& Riediger, M. (2010). Age-related differences in outcome and process goal focus. European Journal of Developmental Psychology, 7(2), 198-222. https://doi.org/10.1080/17405620801969585

Furlong, M. J., \& Christenson, S. L. (2008). Engaging students at school and with learning: a relevant construct for all students. Psychology in the Schools, 45(5), 365-368. https://doi.org/10.1002/pits

Holmes, K., Gore, J., Smith, M., \& Lloyd, A. (2018). An integrated analysis of school students' aspirations for STEM careers: which student and school factors are most predictive? International Journal of Science and Mathematics Education, 16(4), 655-675. https://doi.org/10.1007/s10763-016-9793-z

Kahu, E. R. (2013). Framing student engagement in higher education. Studies in Higher Education, 38(5), $758-773$. https://doi.org/10.1080/03075079.2011.598505

Kahu, E. R., \& Nelson, K. (2018). Student engagement in the educational interface: understanding the mechanisms of student success. Higher Education Research and Development, 37(1), 58-71. https://doi.org/10.1080/07294360.20 17.1344197

Kiyama, J. M., \& Harper, C. E. (2018). Beyond hovering: a conceptual argument for an inclusive model of family engagement in higher education. Review of Higher Education, 41(3), 365-385. https://doi.org/10.1353/rhe.2018.0012

Lam, S. F., Yim, P. S., Law, J. S. F., \& Cheung, R. W. Y. (2004). The effects of competition on achievement motivation in chinese classrooms. British Journal of Educational Psychology, 74, 281-296. https://doi.org/10.1348/000709904773839888 
Matos, L., Reeve, J., Herrera, D., \& Claux, M. (2018). Students' agentic engagement predicts longitudinal increases in perceived autonomy-supportive teaching: the squeaky wheel gets the grease. The Journal of Experimental Education, 86(4), 579-596. https://doi.org/10.1080/00220973.2018.1448746

McMaster, N. C. (2019). What role do students' enjoyment and perception of ability play in social disparities in subject choices at university? British Journal of Sociology of Education, 40(3), 357-377. https://doi.org/10.1080/01425692. 2018.1541311

Monteiro, L., Fernandes, M., Torres, N., \& Santos, C. (2017). Father's involvement and parenting styles in portuguese families: the role of education and working hours. Análise Psicológica, 35(4), 513-528. https://doi.org/10.14417/ap.1451

Novotný, P., Brücknerová, K., Juhaňák, L., \& Rozvadská, K. (2019). Driven to be a non-traditional student: measurement of the academic motivation scale with adult learners after their transition to university. Studia Paedagogica, 24(2), 109-136. https://doi.org/10.5817/sp2019-2-5

Raftery, J. N., Grolnick, W. S., \& Flamm, E. S. (2012). Families as facilitators of student engagement: toward a homeschool partnership model. In S. L. Christenson, A. L. Reschly, \& C. Wylie (Eds.), Handbook of Research on Student Engagement (pp. 343-364). New York: Springer. https://doi.org/10.1007/978-1-4614-2018-7

Reeve, J., \& Shin, S. H. (2020). How teachers can support students' agentic engagement. Theory Into Practice, 59(2), 150-161. https://doi.org/10.1080/00405841.2019.1702451

Reeve, J., \& Tseng, C. M. (2011). Agency as a fourth aspect of students' engagement during learning activities. Contemporary Educational Psychology, 36(4), 257-267. https://doi.org/10.1016/j.cedpsych.2011.05.002

Reschly, A. L., \& Christenson, S. L. (2012). Jingle, Jangle, and conceptual haziness: evolution and future directions of the engagement construct. In S. L. Christenson, A. L. Reschly, \& C. Wylie (Eds.), Handbook of Research on Student Engagement (pp. 3-19). New York: Springer. https://doi.org/10.1007/978-1-4614-2018-7

Silveira, M. E., \& Justi, F. R. R. (2018). Engajamento escolar: adaptação e evidências de validade da escala EAE-4DE. Psicologia Teoria e Prática, 20(1), 110-125. https://doi.org/10.5935/1980-6906/psicologia.v20n1p110-125

Sinval, J., Casanova, J. R., Marôco, J., \& Almeida, L. S. (2018). University student engagement inventory (USEI): psychometric properties. Current Psychology, 40, 1608-1620. https://doi.org/10.1007/s12144-018-0082-6

Timms, C., Fishman, T., Godineau, A., Granger, J., \& Sibanda, T. (2018). Psychological engagement of university students. Journal of Applied Research in Higher Education, 10(3), 243-255. https://doi.org/10.1108/JARHE-09-2017-0107

Toledo, L. D., \& Martínez, T. L. (2019). La experiencia universitaria: Análisis de factores motivacionales y sociodemográficos. Revista de La Educacíon Superior, 48(191), 1-24.

Veiga, F. H. (2016). Assessing student engagement in school: development and validation of a four-dimensional scale. Procedia: Social and Behavioral Sciences, 217, 813-819. https://doi.org/10.1016/j.sbspro.2016.02.153

Veiga, F. H. (2013). Envolvimento dos alunos na escola: elaboração de uma nova escala de avaliação. International Journal of Developmental and Educacional Psychology, 1, 441-450.

Veiga, F. H., \& Antunes, J. (2005). Motivação escolar em função da família na adolescência. In A. B. Lozano (Ed.), Actas do VIII Congresso Galaico-Protuguês de Psicopedagogia, Braga, pp. 1093-1101. Recuperado de http://hdl.handle. net/10451/4805

Veiga, F. H., Robu, V., Conboy, J., Ortiz, A. Y., Carvalho, C., \& Galvão, D. (2016). Students' engagement in school and family variables: a literature review. Estudos de Psicologia (Campinas), 33(2), 187-197. https://doi.org/10.1590/198202752016000200002

Woods, K., \& Frogge, G. (2017). Preferences and experiences of traditional and nontraditional university students. Journal of Continuing Higher Education, 65, 94-105. https://doi.org/10.1080/07377363.2017.1318567

Received: April 27, 2020

Final version: July 22, 2020

Approved: September 21, 2020 